\title{
Nutrient Content Seasonal Dynamics and Local Sources in the Heracleian Peninsula Coastal Waters
}

\author{
E.E. Sovga*, S.I. Kondrat'ev, E.A. Godin, K.A. Slepchuk \\ Marine Hydrophysical Institute, Russian Academy of Sciences, Sevastopol, Russian Federation \\ *e-mail: science-mhi@mail.ru
}

\begin{abstract}
The long-term inter-annual and seasonal variability in 1960-2010 is assessed for certain hydrochemical parameters of the surface and near-bottom layers in the Heracleian Peninsula coastal waters on the basis of the analysis of hydrological and hydrochemical data from the Oceanographic Data Bank of Marine Hydrophysical Institute. The performed analysis allowed one to assess the impact of different nature processes on the distribution of phosphate phosphorus and silicic acid by the annual variation of content of these nutrients. It is shown that for phosphate phosphorus this is the impact of biological processes, and for silicic acid - natural processes related to an increase in fresh water inflow due to spring floods and the presence of submarine fresh water sources. The analyzed long-term data represent the values which are mostly averaged and can be used for this water area as background data.

Complex oceanographic survey of the Heracleian Peninsula water area, carried out in summer and early autumn of 2015 in the area where deep-water sewage discharge of Sevastopol is located, provided an assessment of ecologic situation in this water area. Surface spots of increased turbidity with abnormal values of temperature, salinity and a series of hydrochemical parameters were found. It is determined that these anomalies are related to the outflow of polluted sewage waters to the surface due to the peculiarities of seasonal thermocline formation in the water area under study and possible leakages in case of sewage discharge line rupture. The need for further environmental monitoring of the Heracleian Peninsula coastal zone for developing the scientifically grounded recommendations for improving the ecological situation in the water area under study is confirmed.
\end{abstract}

Keywords: the Herakleian Peninsula, water area, nutrients, inter-annual variability, seasonal variability, expeditionary studies, deep-water discharge.

DOI: 10.22449/1573-160X-2017-1-53-61

(c) 2017, E.E. Sovga, S.I. Kondrat'ev, E.A. Godin, K.A. Slepchuk

(C) 2017, Physical Oceanography

\section{Introduction}

The Heracleian Peninsula is a triangular ledge of land into the Black Sea in the Southwest of the Crimean Peninsula bounded by Sevastopol Bay, the Chernaya River, Balaklava Valley and Balaklava Bay. Its coastal water area is under a significant anthropogenic load and indirect impact of the Sevastopol region bays (Sevastopol, Karantinnaya, Kruglaya, Streletskaya, Kazachya, Kamyshovaya and Balaklava Bays). The anthropogenic load on this water area is determined by discharges of domestic and industrial sewage, recreational activities and an input of pollutants with the surface runoff. The main sewage discharge line of Sevastopol (more than a half of the town's total flow) is situated in the investigated water area. The diffuser of the line is $3.3 \mathrm{~km}$ from the shore at $70-80 \mathrm{~m}$ depth.

All kinds of pollutions including nutrients (in case of their excessive input they may cause a sharp increase in the phytoplankton production which leads to the eutrophication and, in certain situations, to local suffocation phenomena) enter the coastal zones with the surface runoff and discharges of domestic and industrial sewage. Determining the direct effect of various individual pollutants at their joint impact on natural biocommunities is one of the important tasks, but the ecosystem structure usually transforms significantly as a result of such interaction. This could be expressed by both short-term changes (for instance, of ecosystem hydrochemical composition), which are gradually leveled with time owing to natural self-purification processes, and more stable unidirectional changes, which 
have a significant effect on the formation of hydrochemical regime in the given water area and may further lead to violations of normal functioning of biocenoses.

According to satellite data, temperature and salinity surface anomalies, as well as the spots of unknown origin which could occur under both natural (upwelling) and anthropogenic (sewage discharge) factors, were repeatedly noticed in the Heracleian Peninsula coastal waters (in the area between Cape Chersonesus and Cape Fiolent). Determining the Heracleian Peninsula coastal local zones with anomalous values of hydrochemical parameters based on data from a comprehensive oceanographic survey and (as a background) results of the analysis of long-term variability of their values is of a considerable interest in this regard.

Thus, this paper is aimed at assessing long-term inter-annual and seasonal variability of hydrological and hydrochemical parameters in the surface and nearbottom layers of the Heracleian Peninsula coastal waters as well as analyzing the ecological situation in summer and early autumn periods in the area of deep-water sewage discharge according to the results of expeditionary studies in 2015.

\section{Data in use}

To estimate the long-term inter-annual and seasonal variability of hydrochemical parameters in the Heracleian Peninsula coastal water area on the basis of the data from the Oceanographic Data Bank of Federal State Budget Scientific Institution "Marine Hydrophysical Institute of RAS" (MHI BOD), the authors formed a specialized database containing data from 2025 hydrologic and 337 hydrochemical stations accomplished in the water area under study in 1960 2010. Data from 31 oceanographic stations made in an expedition of $R / V$ "Biryuza" (September 2015) are also involved. During this cruise, a hydrochemistry group analyzed 61 samples for dissolved oxygen and $\mathrm{pH}$, collected 244 sea water samples for the further analysis (under conditions of a stationary laboratory) for the nutrient content (phosphates, silicates, the sum of nitrates and nitrites, ammonium), total alkalinity, and inorganic carbon.

The analysis of distribution of the number of stations (Table 1) showed that the most hydrochemical data had been collected in March, May, and November; and the least data were obtained in February and December.

Table 1

Distribution of the number of stations (where hydrochemical data were analyzed) on months and years

\begin{tabular}{l|c|l}
\hline \multicolumn{1}{c|}{ Month } & $\begin{array}{c}\text { Number of } \\
\text { stations }\end{array}$ & \multicolumn{1}{c}{ Years } \\
\hline January & 19 & \multicolumn{1}{c}{$1961,1968,1985,1987$} \\
February & 9 & $1964,1972,1977$ \\
March & 86 & $1961,1965-1967,1969-1970,1975,1996$ \\
April & 12 & $1961-1963,1974$ \\
May & 52 & $1961,1963-1964,1966-1971,1973,1986,1991,2007$ \\
June & 21 & $1965-1967,1969,1978,1987$ \\
July & 32 & $1960-1966,1969-1970,1974,1986,1990-1992$ \\
August & 28 & $1960-64,1967,1969,1976,1086,1992,2009$ \\
September & 26 & $1980,1987,1996,1999$ \\
October & 33 & 1976,2010 \\
November & 46 & $1964,1967-1968,1970,1974-1975,1978-1979$, \\
& & $1985-1987,1989,1993,1998$ \\
December & 8 & 1980,1994
\end{tabular}


It should be pointed out that hydrologic data, as well as the oxygen content and $\mathrm{pH}$, are represented in MHI BOD more completely than the nutrients. Unfortunately, the availability of data on nitrite and nitrate nitrogen distribution was not satisfactory, and the data on the ammonium nitrogen content over the period under study are absent in MHI BOD at all.

\section{The assessments of long-term inter-annual and seasonal variability}

Owing to the insufficient number of performed stations (see Table 1) and their heterogeneous temporal distribution, it was impossible to trace the seasonal variability of the hydrochemical parameters during the whole year for some years of the period under consideration. However, using a large time series gave an opportunity of observing inter-annual seasonal variability within a month for May, March, July, August, and November.

The long-term variability of the content of hydrologic and hydrochemical parameters in the surface and near-bottom layers of the Heracleian Peninsula water area for May was analyzed on the basis of the data given in Table 2. Similar tables were constructed for other months of the year. Then, graphs of the nutrient content annual variability (Fig. 1, 2) were produced using the data averaged over the entire database.

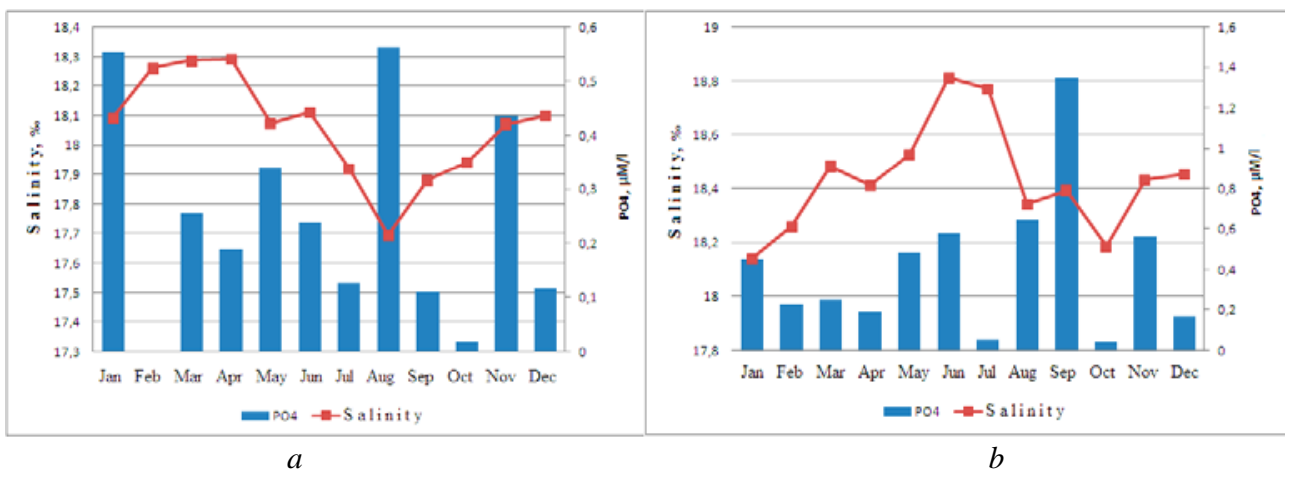

Fig. 1. Annual variability of phosphate content, $\mu \mathrm{M} / 1$, and salinity values, \%o, in the surface $(a)$ and near-bottom $(b)$ layers of the waters averaged over the entire database

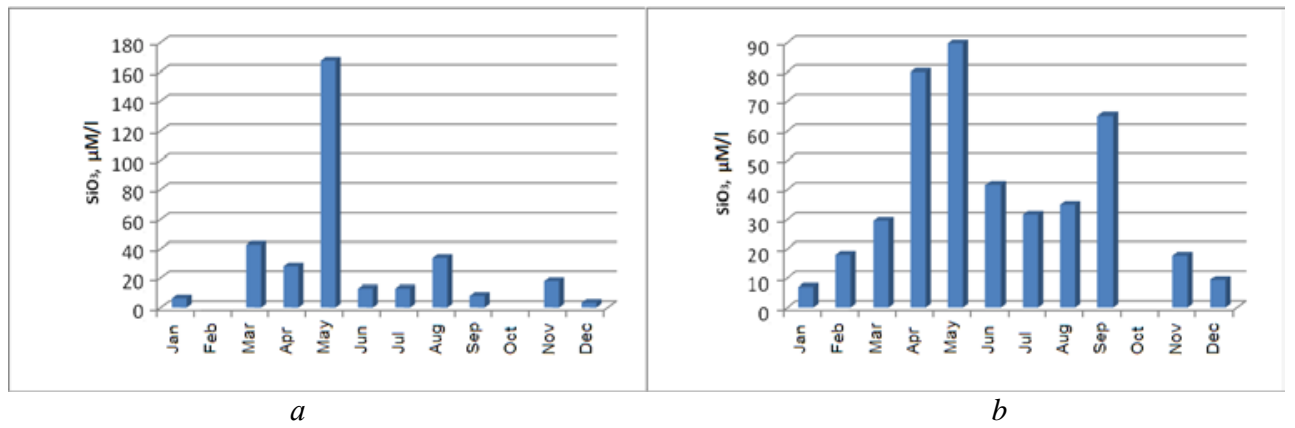

Fig. 2. Annual variability of silicon content, $\mu \mathrm{M} / 1$, in the surface $(a)$ and near-bottom $(b)$ water layers 
Table 2

The hydrochemical regime in the surface and near-bottom layers of the studied water area in May (1960 - 2007)

\begin{tabular}{|c|c|c|c|c|c|c|c|c|c|c|c|c|}
\hline \multirow[b]{2}{*}{ Year } & \multicolumn{3}{|c|}{$\begin{array}{c}\text { Geographical } \\
\text { coordinates of a } \\
\text { sampling point }\end{array}$} & \multicolumn{3}{|c|}{$\begin{array}{l}\text { Sea water hydrologic } \\
\text { characteristics }\end{array}$} & \multirow[b]{2}{*}{$\mathrm{pH}$} & \multicolumn{5}{|c|}{$\begin{array}{l}\text { Oxygen and nutrient content in the water, } \\
\mu \mathrm{M} / 1\end{array}$} \\
\hline & $\begin{array}{l}\Xi \\
\tilde{E} \\
\overrightarrow{0} \\
\hat{a}\end{array}$ & 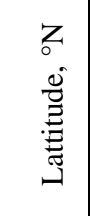 & 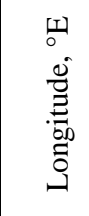 & 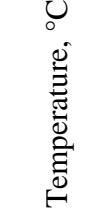 & 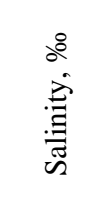 & 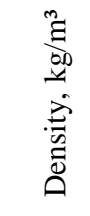 & & $\mathrm{O}_{2}$ & $\mathrm{NO}_{2}$ & $\mathrm{NO}_{3}$ & $\mathrm{PO}_{4}$ & $\mathrm{SiO}_{3}$ \\
\hline \multicolumn{13}{|c|}{ In the surface layer of waters } \\
\hline 25.5.1961 & 0,5 & 44.53 & 33.35 & 14.90 & 17.92 & 12.86 & 8.42 & 288.05 & - & - & 0.097 & 16.02 \\
\hline 24.5.1961 & -"- & 44.55 & 33.26 & 15.10 & 17.68 & 12.64 & - & 266.17 & - & - & - & - \\
\hline 1963 & -"- & 44.55 & 33.35 & 12.30 & 17.76 & 13.19 & 8.48 & 297.88 & 0.071 & - & 0.129 & 328.50 \\
\hline 1966 & -"- & 44.55 & 33.35 & 13.90 & 18.33 & 13.36 & 8.39 & 298.32 & 0.400 & - & 1.130 & 23.99 \\
\hline 1967 & -"- & 44.55 & 33.28 & 15.94 & 17.87 & 12.53 & - & 296.54 & - & - & 0.170 & 16.30 \\
\hline 1968 & -"- & 44.56 & 33.28 & 18.55 & 17.97 & 12.15 & - & 275.10 & - & - & 0.260 & 23.00 \\
\hline 1969 & -"- & 44.56 & 33.26 & 13.80 & 17.92 & 13.06 & - & 300.11 & - & - & 0.390 & 17.30 \\
\hline 1970 & -"- & 44.65 & 33.30 & 14.10 & 18.01 & 13.08 & - & 266.62 & - & - & 0.190 & 18.10 \\
\hline 1986 & -"- & 44.53 & 33.30 & 14.91 & 17.95 & 12.88 & - & 297.43 & - & - & 0.900 & 5.10 \\
\hline 1991 & -"- & 44,60 & 33.28 & 13.92 & 17.76 & 12.92 & - & 257.68 & - & - & 0.490 & 5.10 \\
\hline $2007 *$ & $-"-$ & 44,56 & 33.38 & 12.29 & 18.07 & 13.85 & 8.38 & 298.33 & 0.235 & - & 0.348 & - \\
\hline \multicolumn{13}{|c|}{ In the near-bottom layer of waters } \\
\hline 25.5.1961 & 85 & 44.53 & 33.35 & 7.97 & 18.42 & 14.28 & 8.42 & 279.12 & - & - & 0.71 & 51.58 \\
\hline 24.5.1961 & 100 & 44.55 & 33.26 & 7.89 & 19.07 & 14.80 & - & 143.80 & - & - & - & - \\
\hline 1963 & 90 & 44.55 & 33.35 & 8.02 & 18.69 & 14.49 & 8.44 & 206.77 & - & - & 0.161 & 167.32 \\
\hline 1966 & 85 & 44.55 & 33.35 & 7.90 & 19.47 & 15.11 & 8.10 & 139.33 & 0.364 & - & 0.149 & 39.98 \\
\hline 1967 & 90 & 44.55 & 33.28 & 7.94 & 18.60 & 14.43 & - & 237.59 & - & - & 0.39 & 41.20 \\
\hline 1968 & 95 & 44.56 & 33.28 & 7.77 & 19.33 & 15.02 & - & 200.07 & - & - & 0.32 & 35.10 \\
\hline 1969 & 85 & 44.56 & 33.26 & 7.30 & 18.78 & 14.64 & - & 268.40 & - & - & 0.26 & 51.20 \\
\hline 1970 & 90 & 44.65 & 33.30 & 8.16 & 18.53 & 14.35 & - & 275.98 & - & - & 0.68 & 32.10 \\
\hline 1986 & 91 & 44.53 & 33.30 & 7.35 & 19.42 & 15.12 & - & 114.33 & - & - & 0.76 & 28.10 \\
\hline 1991 & 75 & 44.60 & 33.28 & 7.14 & 18.68 & 14.58 & - & 233.57 & - & - & 0.68 & 12.20 \\
\hline $2007 *$ & 55 & 44.56 & 33.38 & 8.77 & 18.52 & 14.04 & - & 289.84 & - & - & 0.48 & 52.70 \\
\hline
\end{tabular}

*On May 19, 2007 diurnal station from 00.04 to 23.59. 
The performed analysis allowed us to register higher (in comparison with other nutrients) concentrations of silicic acid. This is typical especially for the near-bottom water layer (Table 2). If we compare values of silicic acid concentration in the water area under investigation and in Yuzhnaya Bay $(7-8 \mu \mathrm{M} / 1[1,2])$, which is the most polluted part of Sevastopol Bay, in some years the silicic acid content in the Herakleian Peninsula water area is much higher (Table 2). The situation may resulted from the existence of submarine fresh water sources and the effect of surface runoff, as higher concentrations of silicic acid are always observed in fresh waters [2].

When plotting the annual variability of nutrients, the entire database was averaged and analyzed: annual variability of phosphate and silicic acid content in the surface (Fig. 1, $a ; 2, a$ ) and near-bottom (Fig. 1, $b ; 2, b$ ) layers of water area under study.

From the information given in Fig. 1, it follows that the maximum concentration of phosphate phosphorus $\mathrm{PO}_{4}$ in the surface layer of waters (Fig. 1, $a$ ) is observed in January, November and August, low concentration - in June and September, and the minimum one - in October. The maximum concentration in January and November is related to the natural process of biota decomposition and nutrient release, and the one in August is, apparently, determined by the anthropogenic factors. At the same time, the maximum in August was observed at the maximum temperature and lower salinity. $\mathrm{PO}_{4}$ maximum in the surface layer of waters (Fig. 1, b) was observed in September, the minimum (like in the surface layer) - in October (evidently as a result of the autumn peak of phytoplankton blooming). The data availability on months is quite satisfactory; the data are absent only in February for the surface layer of waters.

The analysis of silicon content seasonal variability (Fig. 2) led to the following conclusions. The maximum concentrations in the surface layer of waters are typical for May with a lower salinity (Table 2). In the near-bottom layer the maximum was also observed in May, moreover, high concentrations were registered in April and September. The minimum values were recorded in winter and autumn in both surface and near-bottom layers.

In this situation an additional research of probable sources of fresh water input increasing the content of silicic acid (spring floods, local foci of submarine unloading, and possible leaks from the sewage discharge line) is necessary.

The analysis revealed the difference between the seasonal variability of the silicic acid and that of phosphorus phosphate content. As far as the phosphorus phosphate (Fig. 1) is concerned, the explicit dependence of its concentration on the ongoing biological processes (the content increase in winter and decrease in spring and summer) is registered, but for silicon acid this dependence is not observed: higher concentrations are observed in May, the minimum ones - in winter (Fig. 2). At the same time, as it is shown in Fig. 2, a, higher concentrations (up to $180 \mu \mathrm{M} / \mathrm{l}$ ) occur in the surface layer of waters.

\section{The analysis of results of expeditionary studies carried out aboard $\mathbf{R} / \mathbf{V}$ "Biryuza” in September 2015}

Taking in-situ measurements during the $2^{\text {nd }}$ cruise of $\mathrm{R} / \mathrm{V}$ "Biryuza" in the Herakleian Peninsula area, the hydrochemistry group performed two polygons (Fig. 3): a macro-polygon with 2 cable length distances between the stations (September 9); a micro-polygon with 100 - 150 m distances between the stations (September 10). 

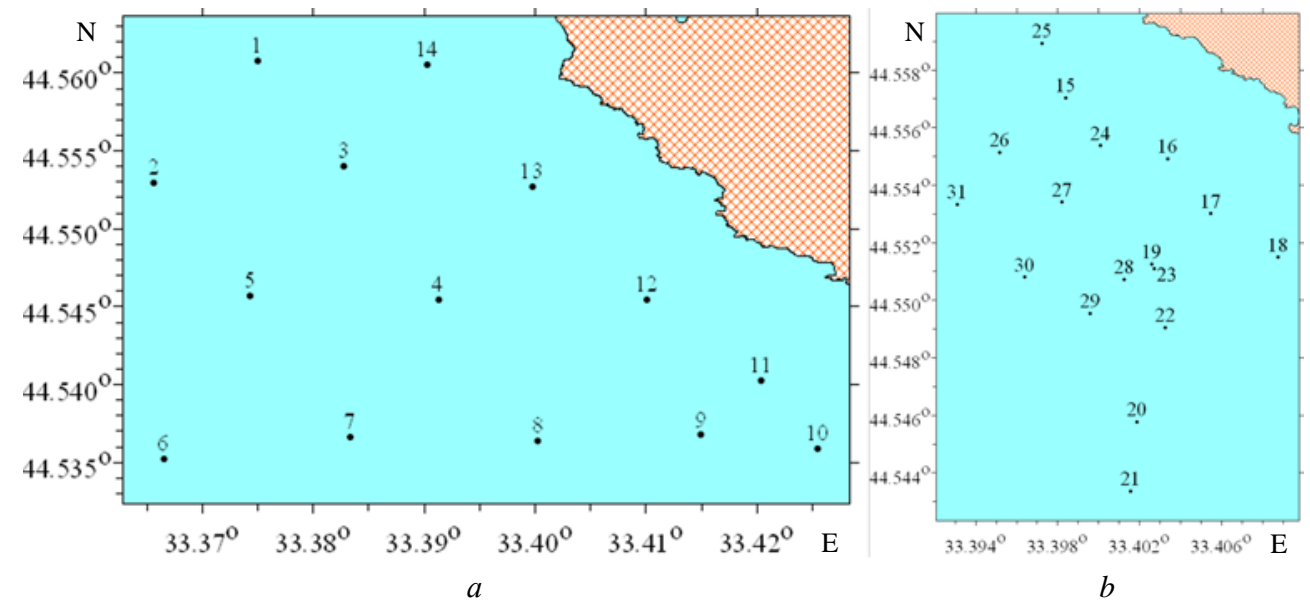

Fig. 3. The schemes of hydrochemical stations carried out by the hydrochemistry group during the cruise at the macro-polygon on September $9(a)$ and at micro-polygon on September $10(b)$

\section{Macro-polygon}

The September 9 investigations indicated the following peculiarities of distribution of hydrochemical parameters in the surface waters: from all the studied nutrients, the excess of phosphates and silicic acid content was rather insignificant in comparison with the background content. The same insignificant excess of concentrations also took place for total content of nitrates and nitrites $(1.2 \mu \mathrm{M} / 1)$ in comparison with $0.9 \mu \mathrm{M} / 1$ background value. A small excess of these parameters was also characteristic of the near-bottom layer of waters. All the values given for the macro-polygon do not exceed ones peculiar to the background concentrations in the shelf open waters.

\section{Micro-polygon}

Micro-polygon survey was carried out on September 10 in that part of water area where a turbid spot $\sim 50 \mathrm{~m}$ in diameter was visually detected on the surface. Presumably, it was a sewage discharge site where higher concentrations of phosphates (from detergents), silicic acid (in fresh river waters its concentration must be higher) and ammonium ions (a product of urea decomposition) should be expected. The distributions of the abovementioned elements in the surface layer of waters are represented in Fig. 4.

According to the data from Fig. 4, $a-c$, at the site of the turbid spot the surface waters contained $1.5 \mu \mathrm{M} / 1$ of phosphates, $2.15 \mu \mathrm{M} / 1$ of silicic acid, $21.4 \mu \mathrm{M} / 1$ of ammonium ions at $0.03,0.24$, and $0.4 \mu \mathrm{M} / 1$ background values, respectively.

The saturation of waters with oxygen (as well as the oxygen content) to the North-East of the turbid spot was higher than at the rest of the polygon. The alkalinity index was $3340 \mu \mathrm{g}$-eqv/l at $3301 \mu \mathrm{g}$-eqv/l background value, $2977 \mu \mathrm{M} / \mathrm{l}$ of total inorganic carbon was contained at a background value of $2920 \mu \mathrm{M} / \mathrm{l}$ (Fig. 4, $d-f$ ).

The total content of nitrates and nitrites was the only hydrochemical parameter which value measured in the surface waters of the turbid spot at station 19 did not differ from the background one and was equal to $1.1-1.2 \mu \mathrm{M} / \mathrm{l}$ for the entire micro-polygon. 
This allows us to assume that storm sewages did not get into the city disposal line in September. As a rule, storm sewages are enriched with nitrates (from inorganic agricultural fertilizers). The abovementioned significantly higher concentrations of phosphates, silicic acid, and ammonium ions in the micro-polygon surface waters were also observed in the near-bottom layers. The ammonium concentration in the surface layer of waters at station 19 was equal to $21.4 \mu \mathrm{M} / \mathrm{l}$ and exceeded the MPC $(20.7 \mu \mathrm{M} /)$.

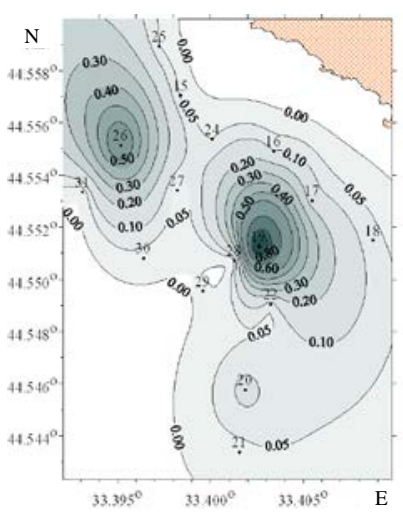

$a$

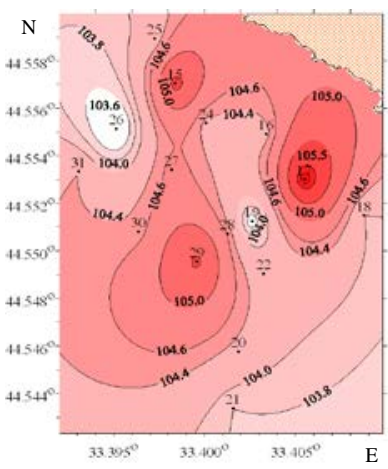

$d$
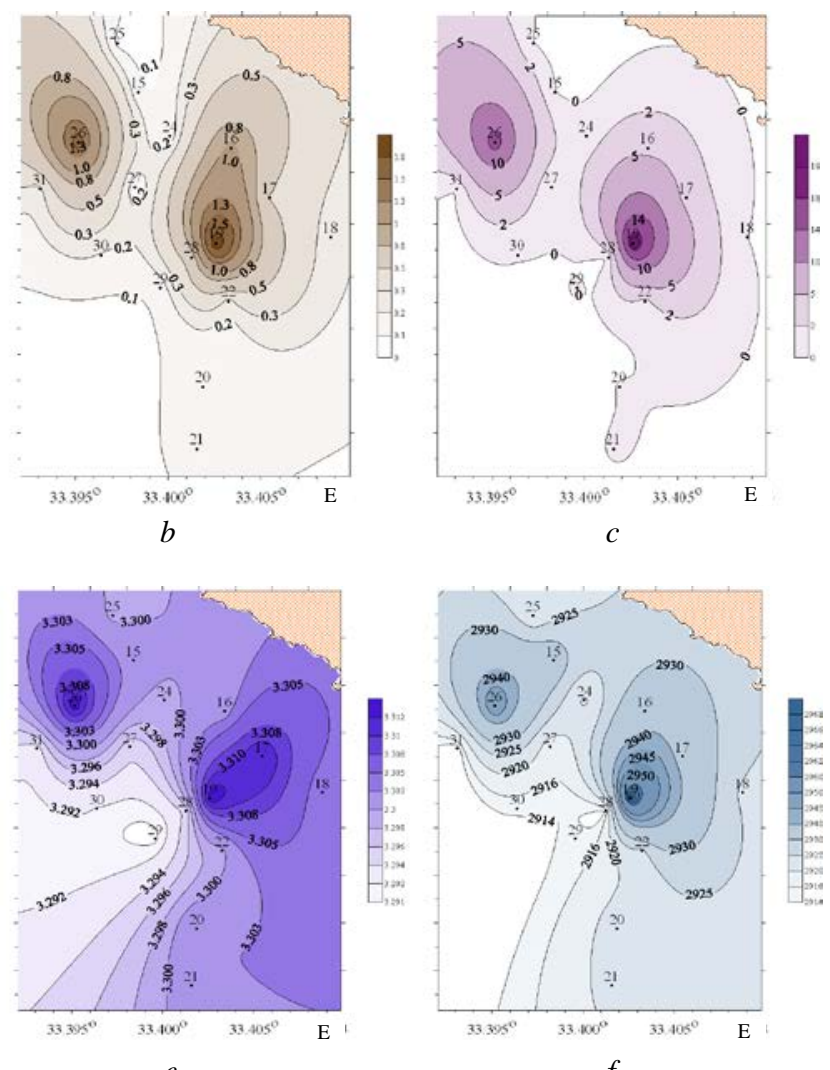

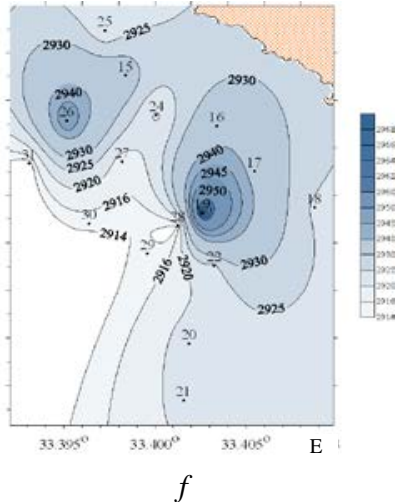

Fig. 4. Surface distribution $(\mu \mathrm{M} / \mathrm{l})$ of phosphates $(a)$, silicic acid $(b)$, ammonium $(c)$ at the micropolygon. Saturation of waters (\%) (d), alkalinity value in $\mu$ g-eqv/l (e) and $\mathrm{TCO}_{2}$ in $\mu \mathrm{M} / \mathrm{l}(f)$ in the surface waters of the Heracleian Peninsula area on September 10, 2015

More scaled survey of this area was performed on September 9 (Fig. 3, a) and did not reveal any features of surface distribution of hydrochemical elements. In the area of the turbid spot found in the surface waters on the following day, the content of phosphates and silicic acid was somewhat higher but this excess was very insignificant when compared to the background content. A slight excess of total nitrate and nitrite concentration $(1.2 \mu \mathrm{M} / \mathrm{l})$ in comparison with the background value $(0.9 \mu \mathrm{M} / \mathrm{l})$ was registered. The increased content of ammonium ions (up to $1 \mu \mathrm{M} / \mathrm{l}$ ) was observed to the North-West and South-East of the turbid spot, while the concentration of ammonium ions in the area of the spot made up $\approx 0.1 \mu \mathrm{M} / \mathrm{l}$.

In the previous expedition (July 2015) surface hydrochemical anomalies were not recorded on a larger scale polygon. The sewage discharge found in September at $\sim 30 \mathrm{~m}$ depth was unable to "break through" the seasonal thermocline in July. The 
surface temperature in September $\left(23^{\circ} \mathrm{C}\right)$ was not too much different from the one in July $\left(26^{\circ} \mathrm{C}\right.$ ), but the water temperature at $30 \mathrm{~m}$ level was $\sim 10{ }^{\circ} \mathrm{C}$ and in September it was equal to almost $22{ }^{\circ} \mathrm{C}$. This means that in September the sewage discharge was located above the seasonal thermocline in the upper quasi-homogeneous layer and freshened waters reached the surface. Thus, the location of the pronounced seasonal thermocline relative to the place of the discharge is a natural factor that can regulate the occurrence of pollutants from the sewage discharge line in the surface layer of waters.

In order to assess the ecological situation in the micro-polygon water area, the nutrient content in the surface and near-bottom layers were compared to that in Yuzhnaya Bay (the most polluted part of Sevastopol Bay). The limits of nutrient content fluctuations at the surface and near-bottom levels in the micro-polygon water area (averaged for certain stations) and in Yuzhnaya Bay according to the average long-term data from [3] are given in Table 3.

Table 3

\section{Comparative data on the nutrient content in the waters of micro-polygon and in Yuzhnaya Bay of Sevastopol at the surface and near-bottom levels}

\begin{tabular}{c|c|c|c|c|c}
\hline \multirow{2}{*}{ Nutrients } & \multicolumn{4}{|c|}{ Content in the water, $\mu \mathrm{M} / 1$} \\
\cline { 2 - 4 } & $\begin{array}{c}\text { At the micro-polygon } \\
10.09 .2015\end{array}$ & $\begin{array}{c}\text { Yuzhnaya Bay water area } \\
\text { (Sevastopol) }\end{array}$ & \multirow{2}{*}{ Note } \\
\cline { 2 - 4 } & $\begin{array}{c}\text { surface } \\
\text { horizon }\end{array}$ & $\begin{array}{c}\text { near- } \\
\text { bottom } \\
\text { horizon }\end{array}$ & $\begin{array}{c}\text { surface } \\
\text { horizon }\end{array}$ & $\begin{array}{c}\text { near-bottom } \\
\text { horizon }\end{array}$ & \\
\hline Silicon & 1.25 & 8.17 & 2.51 & 6.85 & $\begin{array}{c}\text { Excess at the } \\
\text { micro-polygon } \\
\text { Excess at the } \\
\text { micro-polygon } \\
\text { Excess in }\end{array}$ \\
$\begin{array}{c}\text { Nitrites+ } \\
\text { nitrates }\end{array}$ & 13.54 & 4.26 & 2.0 & 2.65 & $\begin{array}{c}\text { Yuzhnaya Bay } \\
\text { Excess at the } \\
\text { Phicro-polygon }\end{array}$ \\
\hline
\end{tabular}

It follows from the Table 3 data that the micro-polygon water area is more polluted with nutrients (except for nitrites and nitrates) than Yuzhnaya Bay. The fact seems to be caused by the location of the Sevastopol sewage discharge line at the micro-polygon.

\section{Conclusions}

The analysis (carried out in the present study) of the long-term data (1960 2010) on the seasonal variability of nutrient content in the water area of the Herakleian Peninsula allowed us to assess, using the annual variability of phosphate phosphorus and silicic acid content, how the processes of various origin effect upon the distribution of these nutrients. Biological processes have a dominant effect on phosphate phosphorus annual variability; and natural processes related to the fresh water inflow increase due to spring floods and unload from submarine sources have the similar effect on silicic acid annual variability.

It should be pointed out that the analyzed long-term data represents mainly averaged values and, therefore, possible anomalies in the content of certain 
hydrochemical elements can be neutralized while averaging. Such anomalies will be more pronounced during a single comprehensive oceanographic survey, but a comparison with the long-term data as a background is necessary to identify them.

As a result of such a comprehensive oceanographic survey of the Heracleian Peninsula water area in the summer and early-autumn periods of 2015, the surface spots of increased turbidity with anomalous values of temperature, salinity, and a number of hydrochemical parameters were found in its coastal zone.

It is ascertained that the revealed anomalies of a number of hydrochemical parameters are caused by the negative effect of the deep-water sewage discharge on the water area ecological state. The obtained results allow us to suggest that the outflow of polluted sewage waters to the surface is related to the peculiarities of seasonal thermocline formation in the water area under study. The possibility of sewage discharge line rupture should not be excluded either. At the same time, it is shown that at the turbid spot location the surface waters contained $1.5 \mu \mathrm{M} / 1$ of phosphates, $2.15 \mu \mathrm{M} / 1$ of silicic acid, $21.4 \mu \mathrm{M} / 1$ of ammonium ions at $0.03 ; 0.24$ and $0.4 \mu \mathrm{M} / 1$ background values, respectively.

The information on the long-term data availability obtained in the research will provide the prospects of more efficient planning and carrying out of the Heracleian Peninsula coastal zone monitoring with the purpose of more efficient evaluation of anthropogenic and natural effects in order to develop science-based recommenddations for improving the ecological situation in the water area under study.

Acknowledgements. The research was carried out within the framework of the State Order No.0827-2014-0010 "Complex interdisciplinary research of oceanographic processes determining the functioning and evolution of the Black Sea and the Azov Sea ecosystems on the basis of modern methods for marine environment monitoring and grid technologies" and partially within the terms of the Agreement No. 2014-10/5-MHI of 10 October 2014 between ISR "AEROCOSMOS" and FSBSI MHI (MHI RAS) as a part of Federal Target Program "Research and development on the priority directions of Russian science and technology complex development for 2014-2020” (RFMEFI57714X0110 project unique identifier, "Diagnostics” code).

\section{REFERENCES}

1. Khoruzhii, D.S. and Konovalov, S.K., 2010. Silicon in Waters of the Sevastopol Bay in Spring 2008. Physical Oceanography, [e-journal] 20(3), pp. 196-206. doi:10.1007/s11110010-9078-y

2. Gevorgiz, N.S., Kondrat'ev, S.I., Lyashenko, S.V., Ovsyany, E.I. and Romanov, A.S., 2002. Rezul'taty Monitoringa Gidrokhimicheskoj Struktury Sevastopol'skoj Bukhty v Teplyj Period Goda [Results of Chemical Monitoring of the Seavastopol Bay during Warm Period]. In: Ekologicheskaya Bezopasnost' Pribrezhnoj i Shel'fovoj Zon i Kompleksnoe Ispol'zovanie Resursov Shel'fa [Ecological Safety of Coastal and Shelf Zones and Complex Use of Shelf Resources]. Sevastopol: MGI NANU. Iss. 6, Vol. 2, pp. 139-157 (in Russian).

3. Ivanov, V.A., Mezentceva, I.V., Sovga, E.E., Slepchuk, K.A. and Khmara, T.V., 2015. Otsenki Samoochishchayushchej Sposobnosti Ekosistemy Sevastopol'skoj Bukhty po Otnosheniyu k Neorganicheskim Formam Azota [Assessment Self-Purification Ability of the Sevastopol Bay Ecosystem in Relation to Inorganic Forms of Nitrogen]". Protsessy $v$ Geosredakh=Processes in Geomedia, [e-journal] 2(2), pp. 55-65. Available at: http://www.geomediacenter.ru/media/PGM_2(2)_2015.pdf [Accessed 20 May 2016] (in Russian). 